UDC 372.881.161.1

DOI: $10.17223 / 24109266 / 9 / 12$

\title{
CASES IN METHODS OF TEACHING RUSSIAN AS A FOREIGN LANGUAGE
}

\author{
O.P. Fesenko, E.V. Fedyaeva, V.V. Bestsennaya \\ Omsk Automotive Engineering Institute (Omsk, Russian Federation) \\ E-mail: Olga.Fesenko2015@yandex.ru
}

\begin{abstract}
The article deals with the specificity of using cases in teaching Russian as a foreign language (RFL) to the adults getting higher professional education or studying Russian for personal goals. The research describes operational phases in the educational process of cases and presents the innovative three-component model of the case. The model is based on features of teaching Russian as a foreign language and takes into account the level of the language proficiency, peculiarities of students and learning environment. The authors define greatest challenges and positive aspects of using cases and lay down their efficiency conditions. The structure of the case developed and proposed in the article can be used in teaching any European language (with some modifications connected with features of culture and everyday life of this or that country). Efficiency of the method, proposed in the article, has been tested at Omsk Tank-Automotive Engineering Institute in the groups with the student number not exceeding 10 persons. The article formulates general methodical requirements and conditions enhancing the productivity of teaching Russian as a foreign language while using cases, positive and negative aspects of cases in methods of teaching Russian as a foreign language.
\end{abstract}

Keywords: a case; Russian as a foreign language; methods of teaching the second language; teaching communication; teaching interactivity.

\section{Introduction}

Among modern methods of teaching Russian as a foreign language the communicative method has occupied the central position for several decades. Teachers aspire to teach a language not as a system (though it is an essential component of the academic content of RFL), but as a mean of communication, to teach oral communication. It means that in the course of acquisition students should not only remember the language system elements, but form skills of productive speech as well, they should speak and listen (that is generate and perceive texts) in communicative situations, adequately estimating their conditions and features. In these context methods of teaching RFL integrate a great number of interactive, communicative and activity approaches and forms which make teaching and learning Russian effective. The methods of case studies is one of these news methods. On the one hand, the theory of case operation in teaching techniques is well-known and developed; on the other hand, it should be updated regularly in the con- 
text of the changing world, education system requirements and the trainees' demands. In this connection we would like to offer to teachers of a higher school establishments and special (for adults) courses devoted to studying RFL a new model of cases allowing to improve teaching process, to enhance its quality and to improve the efficiency of a foreign language learning.

\section{Research Questions}

The method of cases is aimed at finding a solution to "a practically important situation with the view of the conscious acquisition of the content of the subject by the trainees" [1:24]. In case of the higher education system this approach focuses on the formation of competences necessary for realization of the future professional work.

Using the method in our professional sphere - that of teaching RFL has its own specificity. It concerns both the structure of the case and features of its applying in the educational process. That specificity stems from the following: the ultimate goal of the case is development of communication and text construction skills in a foreign language (even if professional terminology becomes the material for the case). So special lexis does not appear at all in the content of the problems taken as a basis of the cases (levels of language mastery A1, A2, B1), or is found in the background (for levels of language mastery $\mathrm{B} 2, \mathrm{C} 1, \mathrm{C} 2$ ). In other words, professional competences development is not a goal in itself of the case method in RFL technique.

We will not dwell upon the general methodical requirements applicable to the use of cases in a modern pedagogical science. Quite a lot has been published about it of late. We are much more interested in the features, which such a case reveals in RFL classes when their communicative potential comes to the foreground.

The use of the case within the limits of RFL assumes the following stages:

1. Getting to know a concrete case, a communicative problem.

2. Accumulation of the necessary information in order to acquire skills necessary for getting and estimating the information that will help in the search of the right solution. At the initial stage of the case solution, a part of the information can be provided preformed.

3. Consideration of possibilities of alternative solutions and development of communicative skills in the course of the solution of communicative problems.

The purpose of the case in teaching RFL - to promote communicative, social and cultural competences of the students, studying Russian as a foreign language. This is achieved by creating speech situations, which are truelife, as much as possible. 
Introduction of the method in teaching Russian as a foreign language makes it is necessary to find answers to some important questions:

1) How should the case model in RFL in terms of the structure of the speech situation look?

2) Is it possible for the case development to systematize all speech situations arising in the course of the students' communication?

3) Can the cases allow implementing individual and split-level approaches in the course of teaching RFL? If it is possible, in what form?

4) What kind of preparation on the part of the teacher and on the part of the trainees is necessary when using cases?

So before developing such cases one has to have a clearvision of the task. It will make it possible even at the very elementary level to involve students into the process of communication.

Firstly, trainees should understand clearly what kinds of problem they are about to solve. It means that the simulated problem should correspond to and correlate with the similar real life, educational or professional one, which the trainee may well come across in their everyday life. If this condition is not met, the problem loses a very important motivational aspect without which the efficiency of training can be called into doubt. Besides, when constructing the problem it is necessary to designate those conditions under which the communication will be carried out. Hence, the problem formulation should be detailed. It can include the name of the participant of communication (your friend, the cashier, the seller, etc.), the communication place (a hotel, a shop, a hospital and so on), an accurate description of the communicative problem (to ask, to specify, to tell, to sympathize, etc.), the communication time (this morning, every day, in the evenings, tomorrow, etc.) and all kinds of further details necessary for efficient communication under the specific proposed case.

Secondly, the case should include the minimum list of auxiliary language or speech materials which could or should (depending on the level of the language acquisition and abilities of a particular student) be used while working on the case. These materials include words, phraseological units, ready speech patterns or phrases.

Thirdly, trainees should know from the beginning what the practical outcome of their work will be. It, as noted above, can be a newspaper, a card, a presentation, a performance or something else. What is important is to be able to create this product in the course of and / or as the result of the organized discussion or to present it in class with its subsequent joint discussion?

\section{Method}

Participants. We would like to add that it is necessary to present the problem so that the information in it has been accurately structured and visu- 
ally well perceived. It provides better acquisition of lexis and speech patterns, allowing the correlation of the task content and possible variants of their solutions. We have developed 80 cases and we used these exercises to 150 students over 3 years.

Materials and Procedure. Taking everything mentioned into consideration we could recommend the following approximate model of the case. We have developed this model of the case, implemented it in the educational process: tion.

1. The problem formulated by means of the text introducing the situa-

2. Key tasks and lexical and / or grammar material and speech patterns, which partially or completely help to find a solution of the problem.

3. Something tangible (a newspaper, an album, Internet page, an audio record and so on) the form of which a trainee ideas should take.

Let us consider some examples of cases for the students studying Russian at the elementary level:

Темье «В столовой. Меню»

Кейс «Конкурс на лучшее меню»

\begin{tabular}{l|l} 
Мануэла приехала из Никарагуа и сейчас & - Здравствуйте! \\
учится в российском медицинском ин- & - Доброе утро! \\
ституте. Каждый день Мануэла ходит в & - Добрый день! \\
столовую на обед. Здесь всё так интерес- & - Добрый вечер! \\
но! Блюда новые, необычные! Что взять & \\
на обед? Как сказать, что вы хотите? & - Скажите, пожалуйста, что это? \\
Ключевые задания: & \\
1) Что в столовой обычно едят на зав- & - Скажите, пожалуйста, это..? \\
трак? на обед? на ужин? & мясо \\
2) Что вы любите есть на завтрак? на & рыба \\
обед? на ужин? & салат \\
3) Ответьте на вопросы: Как лучше спро- & рис \\
сить о меню? Какие варианты просьбы & картошка \\
будут самыми удачными? Почему? & \\
4) Вы - заведующий (начальник) столо- & - У вас есть..? \\
вой. Придумайте название вашей столо- & каша \\
вой и составьте меню. & компот \\
5) Проведите конкурс 'Лучшее меню’ с & хлеб с маслом \\
ваши друзьям. & курица с мясом \\
\multicolumn{2}{|}{ (for readers who do not know Russian language) }
\end{tabular}

Topics 'In the canteen. The menu'

The case 'The best menu competition' 


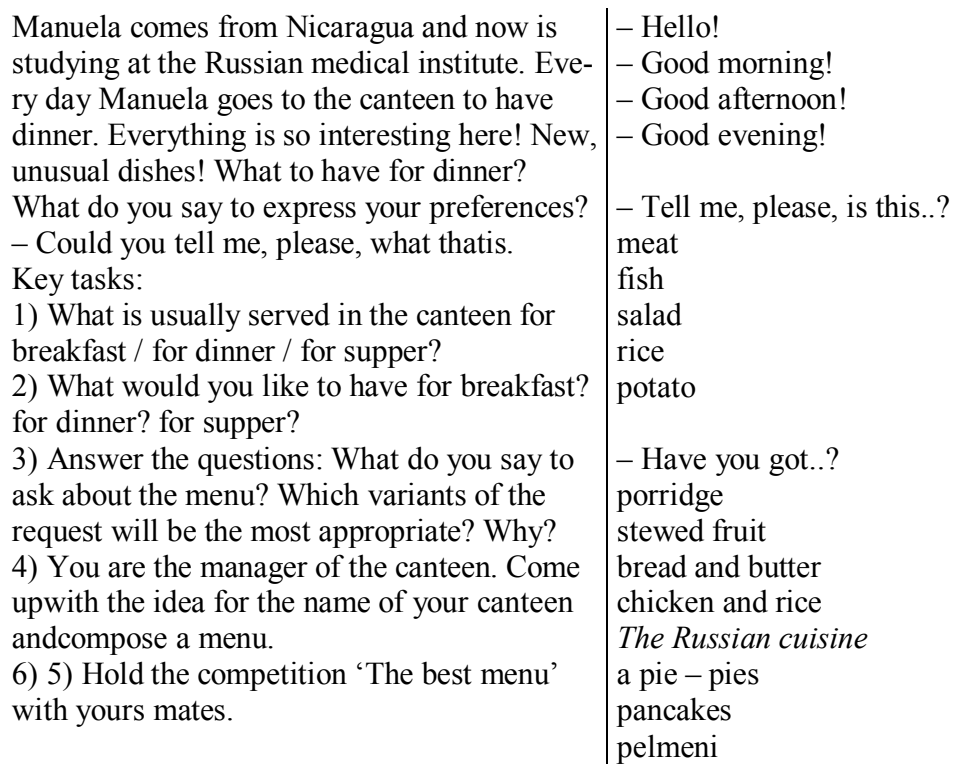

The example provided contains a problem situation: 'How to find out what there is today for dinner and how to order what you would like to have and do it as correctly as possible?' Each of the trainees can offer alternate solutions of the given problem. As a result of the discussion the most productive solution is developed. At the same time, students have a possibility to approach the task solution creatively and whilecomposing their own menu they can use not only the material offered by the teacher, but also attempt to add something of their own. Such anapproach will allow them to bemore convincing during the best menu contest; the results will depend directly on the ability to defend proprietary positions and to join the discussion process. It is quite probable that there will be several winners. Thus all three stages of the problem are consistently realized: 1) getting to know a communicative problem; 2) accumulation of the necessary information in order to acquire skills necessary for getting and estimating the information that will help in the search of the right solution; 3) consideration of possibilities for alternative solutions.

To reach tangible positive results the work on cases solution should be a regular feature of RFL classes. For this purpose it is necessary to develop the tasks, concerning the majority of the themes studied in the course as well as systematize the situations where their use is possible. We have divided such situations into three big groups: household, educational and professional ones. Household situations are connected with the solution of communicative problems arising daily in the trainees' life in the sphere of everyday communication (how to ask the way, to buy tickets to the cinema or some medicine at the drugstore, how to call for a taxi, to get acquainted with a girl, etc.). Educational situations are caused by communicative complexities in 
the sphere of getting education (how to borrow a book from the institute library, how to compose an autobiography for the office of the registrar, etc.). Professional orientation tasks include the problems, which can appear in the sphere of the future professional work of the students. The given type of tasks in teaching RFL at the preparation course does not prevail, as the teacher's aim at this stage is to help form the skills of productive communications without reference to the profession. We would like to provide you with an example of the 'professional' case as they are of the greatest difficulty in studying RFL, because they demand specialized knowledge of the professional sphere and quite a good command of the language both on trainees and on teachers' part:

\section{Тема «Одежда. Форма одежды полицейского» (газета)}

«Сегодня на построении майор Соловьев сделал замечание курсанту из Иордании Ахмету. Он не подшил чистый подворотничок и не почистил ботинки. Майор сказал: “Ты не бережешь свою форму, а значит - не уважаешь полицию!” Как полицейский должен относиться к форме?»

Ключевые задания:

1. Делится ли ваша форма на повседневную, парадную, зимнюю и летнюю? Есть ли в вашей полиции рабочая и парадная форма одежды?

2. Какие предметы одежды входят в вашу форму (повседневную и парадную)?

3. Расскажите о знаках отличия в полиции вашей страны.

4. Подпишите предметы одежды полицейского.

5. Представьте систему погон в виде картинок и подписей к ним.

6. Сделайте общий плакат «Наша полицейская форма».

7. Спросите у вашего соседа по парте о том, какая у него форма. форма: повседневная, парадная, зимняя, летняя

обмундирование

шинель,

пальто,

плащ,

мундир,

китель,

куртка,

тужурка,

брюки,

рубашка,

галстук,

кашне,

перчатки,

пояс,

поясной ремень

обувь:

сапоги,

ботинки,

полуботинки

головной убор:

шапка,

пилотка,

берет,

фуражка

погоны

(for readers who do not know Russian language)

Theme "Clothes. The policeman's uniform" (a newspaper)

“Today on the forming-up Major Solov'ev|theuniform: undress, dress, winter, summer has reprimanded Jordan cadet Ahmet. He did 
not sew on a clear undercollar and did not outfit

clean up his boots. The Major told: "You do a great-coat,

not take care of your uniform, so you disre- a coat,

spect the police!" How should a police officer a raincoat,

regard his uniform?

Key tasks:

a uniform,

a uniform coat,

1. Does your uniform divide into undress, a pea jacket

dress, winter and summer? Are there dress

and undress uniforms in your police?

trousers,

a shirt,

2. What articles of clothing are included into a tie,

your uniform (dressandundress)?

a muffler,

3. Tell about identifying insignia for police in gloves,

your country.

a belt,

4. Put a name to the police officer's articles

of clothing.

a waist belt

shoes:

5. Present the system of shoulder boards in pictures and captions to them.

knee-high boots,

6. Make a general poster "Our police uniboots, form".

7. Ask your desk neighbor aboutthe uniform in his country.

low shoes

a cover:

a cap,

a fore-and-aft cap,

a beret,

a cloth cap,

shoulder boards

Effectiveness of this kind of work depends not only on the regularity factor but also on the fact that it is repeated throughout all levels of learning Russian as a foreign language.In other words, at the elementary level it could be a story about oneself in a newspaper format with pictures and a text. At the first certification level, a presentation or an album accompanies the story; the story could contain new information about the trainee (e.g., his vision of himself in 10 years time).

In the process of a case compilation, a teacher, certainly, needs to follow the requirements of the State Standards for Russian as a foreign language [2] or other documents, regulating the educational content of Russian as a foreign language. In other words, the level of the task complexity, its lexical and grammatical content should comply with the level of the language acquisition. However, it does not mean that a trainee has to use only that lexis or that grammar, which is given in an exercise. A student is free to make use of the wide variety of lexical and grammatical resources accessible for him to cope with the task. In such situations, the case method facilitates the problem solution by providing a supporting scheme / pattern. That certainly simplifies the process of finding the correct solution and at the same time does not impose any restrictions.

Besides, cases can be used at different phases of the language acquisition: elementary, basic, the first certification, etc. It is the teacher's aimis to 
represent tasks and a problem methodically correctly (taking into account specifications, the trainee's age and abilities).

For example, at the elementary level it could be a newspaper, a booklet or a table:

Тема «Моя страна / мой родной город». Рекламный буклет

Студент Гансух приехал из Монголии. А Томе - из Мозамбика. Вот Лисбан. Он с Кубы. А это Ахмед из Иордании... Сколько стран учится на специальном факультете нашего института? Больше 20! Давайте путешествовать. Сделайте рекламный проспект с информацией о своей стране и расскажите об интересных местах, где вы советуете побывать своим друзьям из других стран.

Ключевые задания:

1) Найдите в интернете фотографии, на которых есть красивые и интересные места вашей родины.

2) Подумайте, что вы о них расскажете. Почему вы советуете поехать туда и увидеть это «своими глазами»?

$3)$ Сделайте рекламный буклет (2-4 листа картона). Наклейте фотографии и напишите информацию об этом месте.

\author{
страна \\ город \\ столица \\ язык \\ океан \\ море \\ река \\ водопад \\ гора - горы \\ музей \\ памятник \\ национальный парк \\ пейзаж \\ путешествовать \\ красивый \\ популярный \\ интересный
}

(for readers who do not know Russian language)

\section{Theme "My country / Myhome town". Anadvertising brochure}

Student Gansuh comes from Mongolia. Tomeis from Mozambique. Here is Lisban. He is from Cuba. And this is Ahmed from Jordan... Representatives of how many countries study at the special faculty of our institute? More than 20 ! Let us travel. Make anadvertising brochure with the information on your country and talk about interesting places, which you advise your friends from other countries to visit.

Key tasks:

1) Find pictures with beautiful and interesting places of your native land on the Internet.

2) Think what you will say about them. Whydo you advise to go there and see it "with one's own eyes"?

3) Makeabrochure (2-4 cardboard sheets). Paste on pictures and write the information about these places.

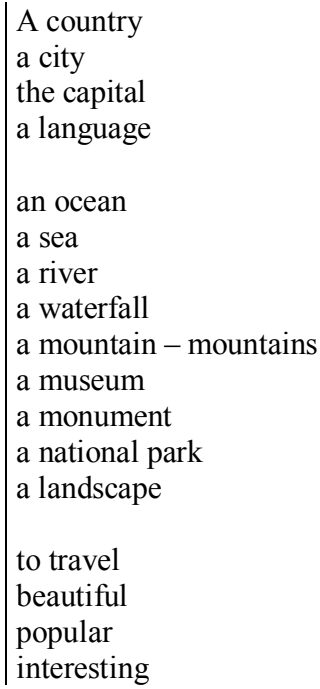

At the basic level, a product, which is necessary to create, could be more complicated, for example, a collage: 
Тема «Мой институт» (коллаж)

«Жорж волнуется. Вчера он приехал из Анголы в Россию. Новый незнакомый город встретил Жоржа снегом и морозом. У него ещё нет друзей, и он совсем не знает институт. Где столовая? Где библиотека? Где он будет учиться? С кем он будет жить в одной комнате?»

Ключевые задания:

1) Нарисуй план института. Напиши, что где находится? Объясните Жоржу, как пройти в столовую, библиотеку, где находятся учебный корпус, стадион, бассейн, общежитие.

2) Сфотографируй или нарисуй интересные моменты из жизни института.

3) Создай коллаж, в который войдут рисунки и фото из жизни института, и подписи к ним. Объясни, почему ты выбрал именно их.

столовая
чайная
стадион
бассейн
библиотека
кафедра русского языка
корпус
общежитие
чайная
повернуть налево
повернуть направо
пройти прямо
идти до (чего?)
(что?) находится (где?)

(for readers who do not know Russian language)

Theme "My institute" (a collage)

"George is worried. Yesterday he arrived from Angola in Russia. A new unknown city met George with snow and frost. Hehas not madeany friends yet, and he does not know the institute at all. Where is the canteen? Where is the library? Where will he study? With whom will he live in one room?"

Key tasks:

1) Draw the institute plan. Write, what and where is situated.Explain to George how to gettothe canteen, the library, where the teaching block, the stadium, the swimming pooland the hostel are situated.

2) Take a photo or draw interesting momentsofthe institute life.

3) Create a collage, which will contain drawings and photosof the institute life and captionsto them. Explain why you have chosen them. a canteen
a tea-house
a stadium
a swimming pool
a library
the Russian language department
a teaching block
a hostel
a tea-house
turn left
turn right
go straight ahead
go as far as (what?)
(what?) is situated (where?)

The first certification level of the language acquisition allows a trainee to cope with the tasks that are more difficult than making presentations, working with tables etc. At this level trainees may be involved in making reports which take into account style requirements, filling up a form or giving an instruction:

Тема «Путешествие. Билет на самолет»

Скоро каникулы. Вы планируете поехать домой, потому что впереди два месяца отдыха. Вам нужно по Интернету заказать билет на самолет до вашего родного города.
Интернет сайт 
Ключевые задания:

1. Найдите в интернете сайт нужной вам авиакомпании, например «Аэрофлот».

2. Найдите на сайте раздел «Правила бронирования и оплаты билета». Прочитайте его. Обязательно поставьте галочку, что вы с этими правилами ознакомлены и согласны.

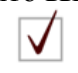

3. Найдите на сайте раздел «Купить билет» или «Забронировать билет».

4. Заполните нужные вам требования в заявке на покупку (бронирование) билета (откуда, куда, билет «туда и обратно» или только «туда», дату отправления, количество билетов, класс обслуживания, валюта оплаты).

5. Узнайте, в какие сроки необходимо выкупить билет.

6. Составьте инструкцию для товарищей «Как забронировать билет на самолет»

бронировать / забронировать

бронь

бронирование

пункт назначения

класс обслуживания

- эконом

- комфорт

- бизнес

валюта

ознакомиться с правилами

поставить галочку

оплатить

оплата

выкупить бронь

инструкция

(for readers who do not know Russian language)

Topic "Travelling. The flight ticket"

The vacations are just round the corner. You plan to go The Internet

home, becausethere are two months of rest ahead. You a site

need to book the flight ticket over the Internet to your hometown.

book / make a reservation

booking

Key tasks:

reservation

1. Find on the Internet a site of theairline you need, for example "Aeroflot".

a destination

2. Locate the site section entitled "Rules of the reserva- a service class

tion and the ticket payment". Read it. Be sure to tick the - economy

box that you have read, understood and agreed with these - comfort

rules.

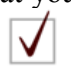

- business

currency

3. Find the site section "Buy a ticket" or "Reserve a ticket".

4. Fill in the necessary information concerning your flight (where from, where, a return ticket or one-way ticket, the departure date, number of tickets, a service class and payment currency).

5. Find outthe information about the time periodin which youhave to redeem your ticket.

6. Write out the instruction for your groupmates "How to reserve the flight ticket"

have a look at the rules

tick the box

to pay

payment

redeem a ticket

an instruction

\section{Results}


The results of the final phase of the experiment indicate a significant improvement of the quality skills through regular reference to case studies as shown in Table 1 and Table 2.

The results of the exam in the preparatory course (2013)

\begin{tabular}{|c|c|c|c|c|c|c|}
\hline 150 students & 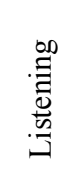 & 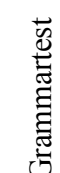 & $\begin{array}{l}\stackrel{00}{:} \\
\stackrel{\Xi}{\mathbb{E}} \\
\widetilde{\simeq}\end{array}$ & 告 & 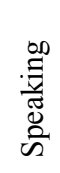 & $\begin{array}{l}\stackrel{\mathscr{n}}{\Xi} \\
\mathscr{\tilde { D }} \\
\mathscr{\simeq}\end{array}$ \\
\hline AVERAGE SCORE (maximum 5) & 2.6 & 3.2 & 2.6 & 4.3 & 4.3 & 3.3 \\
\hline
\end{tabular}

T a ble 2

The results of the exam in the second year (2016)

\begin{tabular}{|c|c|c|c|c|c|c|}
\hline 150 students & 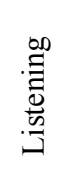 & 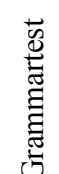 & 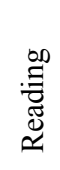 & 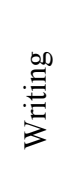 & 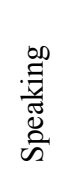 & 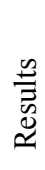 \\
\hline AVERAGE SCORE (maximum 5) & 4 & 3.9 & 4 & 4.3 & 4.6 & 4 \\
\hline
\end{tabular}

Creation of projects (newspapers, instructions, presentations, etc.) should not become a goal in and of itself. This work should become the means of language acquisition, helping to organize speech communication: a story with the following discussion of its content, a discussion, a dialogue, a role-playing game.

\section{Conclusions and discussion}

If you carefully analyze structural features and the content of the cases, it is not too difficult to notice that their use in the teaching process has advantages and disadvantages (for both the teacher and the student).

Benefits of the case method for the trainee:

1. Increase of motivation and interest in a subject.

2. Development of the trainees' independence and commitment; they learn to set realistic goals. 
3. The level of trainees' knowledge, the width of their outlook and the depth of their experience are expanded.

4. Better acquisition of the learning material.

5. Development of teamwork skills, social skills and the ability to provide feedback.

6. Formation of problem solving habits, foreseeing all possible consequences of the decisions made, understanding the ways a problem may be approached, decision - be made and substantiated.

7. Acquisition of the ways decisions are reached and rationalized.

8. Activation of trainees' stand to social issues promoting stress resistance and ability to respond to challenges.

9. Enhancement of trainees ability to experiment, hypothesize and find evidence.

10. Accumulation of experience to work with the information, to solve problems and to make decisions.

Benefits of the case method for the teacher:

1. Enrichment of the teacher's creativity potential in the process of search for new opportunities for material presentation.

2. Using the possibility of direct adaptation of scholarly advance stop articular situations and conditions.

3. Integration of the teaching material within the frameworks of the separate block at different levels (intersubject, metasubject and personal) that allows to achieve several objectives simultaneously - training, educational, organizing and research.

Disadvantages of the case method:

1. Making a case and working with it is always a creative process, requiring "erudition, pedagogical skills and time for selection of appropriate actual information in which a professional situation is modelled and the body of knowledge, know-how, which students need to acquire, is reflected".

2. Impossibility to apply this method at the first phases of learning a language. Application of the case method is in effective without first obtaining necessary knowledge in the subject and the theme.

3. A certain level of the students' training, such as primary team works kills and the level of communicative competence, which is relevant to the case.

4. High effectiveness of this method is contingent on its combined application with other teaching methods.

In summary, the use of the cases requires some efforts from both a teacher and a student. A teacher should prepare information, arrange it in a proper way, define the tasks and think over the work system. A student needs a lot of time for its realization. Most of ten it is possible to complete the case only outside the classroom at self-instructional time for the subject. 
For the most effective work in the framework of the method, it is necessary to consider a set of conditions, without observation of which the use of the case method cannot be productive:

1. The realization takes a lot of time. Sometimes- to solve a casestudents need to give it the time reserved for self-instruction. It means that the task should be represented in such a way that students would not have any difficulties in understanding it. Certainly, it is necessary to give explanations in class.

2. The wish to use modern methods of RFL teaching and the level of a teacher's professional competence. Cases take a lot of time and intellectual resources (for both preparation and organization) as well as for careful premeditation of the method place in the system of other teaching methods. As a result not every expert is ready and eager to use this method.

3. Communicative experience of students and the group characteristics. It is necessary to prepare the performance of such exercises psychologically. Students should not have a desire to laugh at the conversation partner in the course of the solution or the presentation of the case. The teacher's go a lis to create a positive communicative atmosphere and willingness to succeed. It is especially important when the group consists of students from different countries.

4. Preservation of the proposed visual pattern of the case assuming its division into two parts: informative (with the text description of the situation) and supportive (with the speech patterns and the words).Such a structure facilitates greatly the perception of the material at initial stages of studying Russian as a foreign language.

5. Small student groups (no more than 10 persons). Otherwise not every trainee can take part in the case solution, which means that the quality of the material acquisition might leave much to be desired.

The authors believe that teaching Russian as a foreign language could be characterized as interesting, communicative and successful provided a competent teacher makes an effective use of combination of the traditional teaching methods and the cases. It is necessary to pay attention to the choice of suitable tasks, their accordance to the current reality, application of the knowledge received in class and the students' psychological readiness for dealing with such cases. All these theoretical and practical issues should be taken on board while determining long-term goals consisting in training internationally recognized and possessing necessary theoretical and practical skills and knowledge specialists.

\section{References}

1. Bondar, E.N. (2015) Formirovanie universal'nyh uchebnyh deystviy uchaschihsya na urokah himii posredstvom resheniya situatsionnyh zadach. Vestnik nauchnyh konferentsiy. $1-3$. pp. 24-25. 
2. (2009). Gosudarstvennye standarty po russkomu yazyku kak inostrannomu. Elementarny uroven Bazovy uroven. Pervy sertifikatsionny uroven. SPb. 48.

Resived 02.05.2017

Information about the authors:

Fesenko Olga - Associate Professor, Professor at the Department of Foreign and Russian Languages, Omsk Automotive Engineering Institute (Omsk, Russian Federation). E-mail: Olga.Fesenko2015@yandex.ru

Fedyaeva Elena - Associate Professor, Professor at the Department of Foreign and Russian Languages, Omsk Automotive Engineering Institute (Omsk, Russian Federation). E-mail: Olga.Fesenko2015@yandex.ru

Bestsennaya Victoria - Associate Professor, Professor at the Department of Foreign and Russian Languages, Omsk Automotive Engineering Institute (Omsk, Russian Federation). E-mail: Olga.Fesenko2015@yandex.ru 